\title{
Study to assess the effectiveness of Planned Teaching Program on knowledge regarding Basic Life Support among students in Pathania Public School, Rohtak, Haryana
}

\author{
Monika Dahiya ${ }^{1}$, Milan $^{2}$ \\ ${ }^{I}$ College of Nursing, Pt. B D Sharma Post Graduate Institute of Medical Sciences, Rohtak, Haryana \\ ${ }^{2}$ Haryana College of Nursing, Ellenabad, Sirsa, Haryana
}

\begin{abstract}
A Pre-Experimental One Group Pre-test Post-test study was conducted to assess the Effectiveness of Planned Teaching Program on knowledge regarding Basic Life Support among 200 school students from $9^{\text {th }}$ and $10^{\text {th }}$ standard from Pathania Public School, Rohtak, Haryana by using simple random sampling technique. Structured knowledge questionnaire was used to assess the knowledge of school students. The findings of the study revealed that the mean post test scores were significantly higher than mean pre test scores.
\end{abstract}

Keywords: Planned Teaching Program, Knowledge, Basic Life Support, School, Students,

\section{Introduction}

Heart disease is the world's largest killer, claiming 17.5 million lives every year. About every 29 seconds, an Indian dies of heart problem. As many as 20,000 new heart patients develop every day. In India 9 core Indian suffer from heart disease and 30\% more are at high risk. Cardiovascular diseases now more prevalent in India and China than all economically developing countries in the world combined. Cardiovascular disease in India quadrupled in the last 40 years. WHO estimates that by 2020 close to $60 \%$ of cardiac patients worldwide will be Indian. Basic life support is commonly taught to the general public and the new generation as these may be the only ones present in the crucial few minutes before emergency personnel are available.

"To think too long about doing a thing often becomes its undoing."

Basic Life Support is the fundamental technique for the emergency treatment of cardiac arrest. For every minute that passes after a patient goes into cardiac arrest their chance of survival decreases by seven to 10 per cent until a defibrillator arrives (Metcalfe-Smith, 2003). A patient who has suffered sudden cardiac arrest must receive effective treatment as soon as possible. When delivered promptly, resuscitation can save the lives of many patients in cardiac arrest.

Aims and Objectives of the Study

$>$ To assess the existing level of knowledge of the students regarding basic life support.

$>$ To determine the effectiveness of planned teaching program on basic life support in terms of gain in knowledge score among the students.

\section{Materials and Methods}

The present study was conducted to assess the effectiveness of Planned Teaching Program on knowledge regarding Basic Life Support among students in Pathania Public School, Rohtak, Haryana. Pre Experimental (One Group Pretest Posttest) research design was used in the study using simple random sampling technique and sample size was 200. Data was collected by structured questionnaire regarding knowledge Basic Life Support among students in Pathania Public School, Rohtak, Haryana in the month of January and February 2013. Descriptive and inferential statistics were employed to analyze the data.

\begin{tabular}{|c|c|c|c|c|c|}
\hline Sr. No. & & & Demographic Variables & Frequency & Percentage (\%) \\
\hline \multirow[t]{4}{*}{1.} & \multirow{4}{*}{$\begin{array}{l}\text { Age } \\
\text { (in years) }\end{array}$} & a. & $10-12$ & 0 & 0 \\
\hline & & b. & $13-15$ & 88 & 44 \\
\hline & & c. & $16-18$ & 112 & 56 \\
\hline & & d. & More than 18 & 0 & 0 \\
\hline \multirow[t]{2}{*}{2.} & \multirow[t]{2}{*}{ Gender } & a. & Male & 113 & 56.5 \\
\hline & & b. & Female & 87 & 43.5 \\
\hline \multirow[t]{5}{*}{3.} & \multirow[t]{5}{*}{ Religion } & a. & Hindu & 192 & 96 \\
\hline & & b. & Muslim & 2 & 1 \\
\hline & & c. & Sikh & 6 & 3 \\
\hline & & d. & Christian & 0 & 0 \\
\hline & & e. & Others & 0 & 0 \\
\hline \multirow[t]{2}{*}{4.} & \multirow{2}{*}{$\begin{array}{l}\text { Type of } \\
\text { Family }\end{array}$} & a. & Nuclear & 127 & 63.5 \\
\hline & & b. & Joint & 73 & 36.5 \\
\hline
\end{tabular}




\begin{tabular}{|c|c|c|c|c|c|}
\hline \multirow[t]{3}{*}{5.} & \multirow{3}{*}{$\begin{array}{l}\text { Place of } \\
\text { Living }\end{array}$} & a. & Rural Area & 23 & 11.5 \\
\hline & & b. & Urban Area & 146 & 73 \\
\hline & & c. & Semi- Urban Area & 31 & 15.5 \\
\hline \multirow[t]{5}{*}{6.} & \multirow{5}{*}{$\begin{array}{l}\text { Parent's } \\
\text { Occupati } \\
\text { on }\end{array}$} & a. & Unemployed & 0 & 0 \\
\hline & & b. & Labourer & 0 & 0 \\
\hline & & c. & Self- employed & 41 & 20.5 \\
\hline & & d. & Private Job & 53 & 26.5 \\
\hline & & e. & Govt. Job & 106 & 53 \\
\hline \multirow[t]{4}{*}{7.} & \multirow{4}{*}{$\begin{array}{l}\text { Monthly } \\
\text { Income } \\
\text { (in Rs.) }\end{array}$} & a. & $1000-5000$ & 0 & 0 \\
\hline & & b. & $5,000-10,000$ & 0 & 0 \\
\hline & & c. & $10,000-20,000$ & 31 & 15.5 \\
\hline & & d. & $>20,000$ & 169 & 84.5 \\
\hline \multirow[t]{4}{*}{8.} & \multirow{4}{*}{$\begin{array}{l}\text { Source of } \\
\text { Informati } \\
\text { on }\end{array}$} & a. & Television & 72 & 36 \\
\hline & & b. & Newspaper & 23 & 11.5 \\
\hline & & c. & Radio & 0 & 0 \\
\hline & & d. & Internet & 105 & 51 \\
\hline
\end{tabular}

\section{Results}

The Study articulated that the overall post-test mean with $\operatorname{SD}(21.31 \pm 3.80)$ was higher than pre-test mean with $\mathrm{SD}(14.42 \pm 3.75)$ with mean difference of 6.89 . ' $\mathrm{t}$ ' value was computed to find the level of significance between the means and it was observed highly significant ( ' $t$ ' $\left.{ }_{199}=50.26\right)$ at $p<0.05$. This result reveals that the planned teaching programme was effective in increasing the knowledge of the students regarding basic life support.

\begin{tabular}{|l|l|l|l|l|l|l|}
\hline Group & Mean & SD & Mean difference & 't’ value & df & Significance / Not significant \\
\hline Pre-test $(\mathrm{n}=200)$ & 14.42 & 3.75 & 6.89 & 50.26 & 199 & HS $<0.05$ \\
\cline { 1 - 3 } Post-test $(\mathrm{n}=200)$ & 21.31 & 3.80 & & & & \\
\hline
\end{tabular}

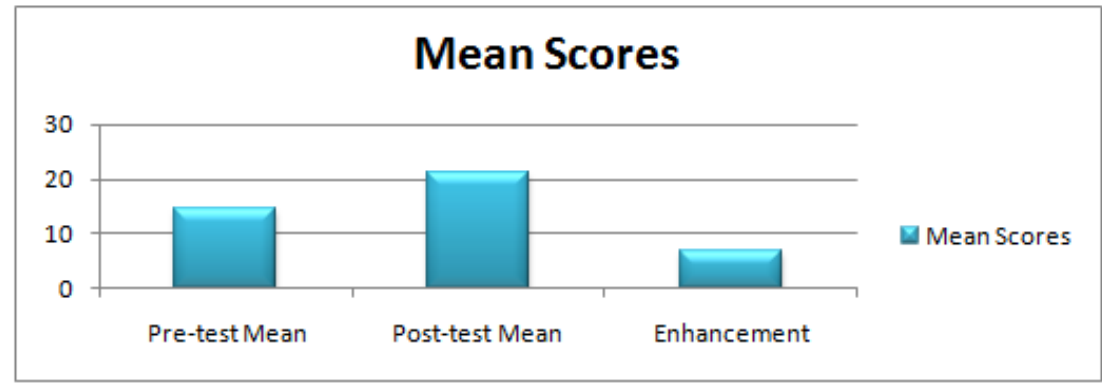

\begin{tabular}{|l|l|l|l|l|l|}
\hline \multirow{2}{*}{ Level of knowledge } & \multirow{2}{*}{ Range of scores } & Pre-test & Post-test \\
\cline { 3 - 6 } & & Frequency & \% & Frequency & \% \\
\hline Adequate & $21-30$ & 0 & 0 & 164 & 82 \\
\hline Moderate & $11-20$ & 154 & 77 & 36 & 18 \\
\hline Inadequate & $0-10$ & 46 & 23 & 0 & 0 \\
\hline
\end{tabular}

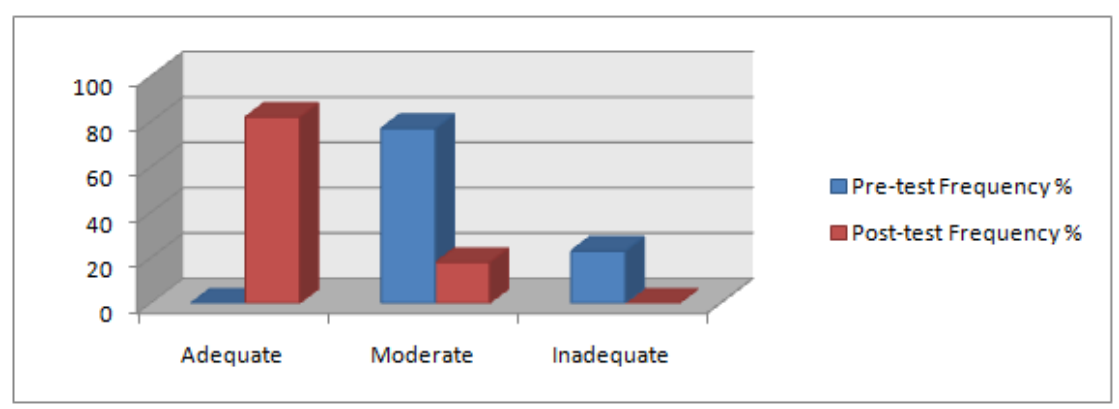

Table-: Significance of the difference between pre-test and post-test knowledge score

\begin{tabular}{|c|l|l|l|}
\hline Areas & Mean Effectiveness & 't' value & Level of significance \\
\hline Introduction of BLS & 0.35 & 7.45 & HS $<0.05$ \\
\hline Techniques of BLS & 5.16 & 42.71 & HS $<0.05$ \\
\hline
\end{tabular}




\begin{tabular}{|l|l|l|l|}
\hline Post resuscitation care & 1.39 & 16.69 & HS $<0.05$ \\
\hline Overall & 6.89 & 50.26 & HS $<0.05$ \\
\hline
\end{tabular}

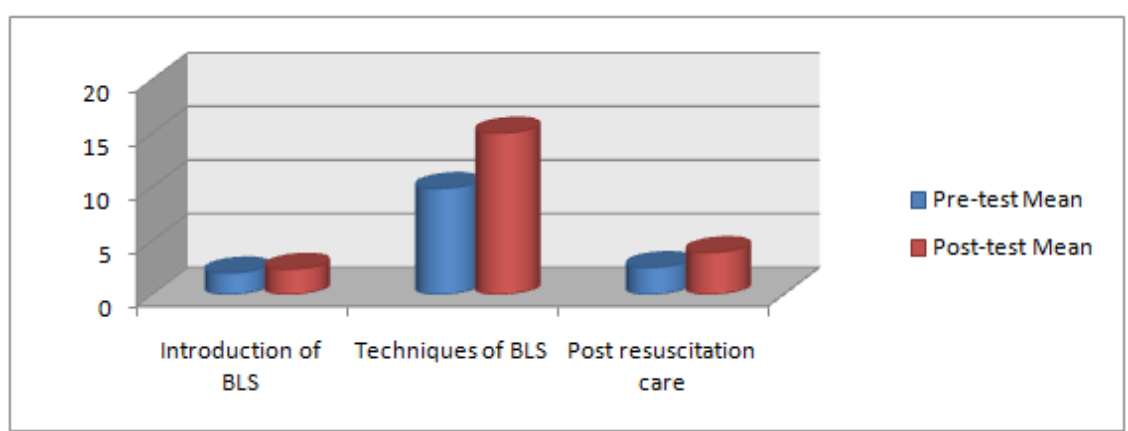

\section{Discussion}

Findings in the present study revealed that the planned teaching programme was effective in increasing the knowledge of the students regarding basic life support. The result of the study are supported by Anil Kumar Parashar (2010) conducted a study to assess the effectiveness of planned teaching programme (PTP) on knowledge and practice of Basic Life Support among 40 high school students in Mangalore through simple random sampling technique. The study showed that majority (87.5\%) of the students had inadequate knowledge and $(100 \%)$ had poor practice. The planned teaching programme facilitated them to update their knowledge and practice related to Basic Life Support.

Velhal G.D. (2004) conducted a study among 783 secondary school students in Bombay to assess the knowledge about BLS-CPR knowledge with the help of pre-tested multiple choice type of questionnaire. Study revealed that only $13 \%$ of students knew that CPR is the life saving measure, whereas $87 \%$ has never heard about CPR. Researcher strongly recommends the health professional to provide education to the students which cover the major portion of the general population.

Miro O. et al. (2002) conducted a study to assess the effectiveness of planned teaching programme basic cardiopulmonary resuscitation to teenagers within high school age between 14-20 years. Participants who had previously taken a first-aid course or were in the course obtained significantly better marks than the rest. These differences disappeared after process completion. Students rated the theoretical parts as 7.9(1.1) the skill part as 8.2(1.2) study concluded that PTP is useful in improving student's knowledge and skills in CPR.

Sangeetha Krishnan; (2002) conducted a study to evaluate the effectiveness of PTP on CPR technique among 60 staff nurses in selected hospital in Bangalore City. Quasi experimental research design was used. The total mean percentage of post-test knowledge score was $97.10 \%$ with enhancement of $46.9 \%$ $(\mathrm{SD}=3.7)$ which shows gain in knowledge after implementation of PTP. It was found that planned teaching programme on CPR has enhanced, reinforced the knowledge and improvement regarding CPR technique.

\section{References}

[1]. Basic Life Support. Wikipedia Free Encyclopaedia. Available from: http://Wikipedia. org:14

[2]. Swarpin GM. Necessity of teaching CPR in colleges. Doller AMJ Publ Health 1999:849-52.

[3]. Heitkemper L, O'Brien DB. Medical Surgical Nursing. $7^{\text {th }}$ ed. Noida: Elsevier Publication 2007:1141-47.

[4]. Russell D, Metcalfe S. Performing Basic Life Support. Nursing Practice Clinical Research 2003;99:20-4.

[5]. Docherty B. Basic Life Support and AED. Clinical Manager Cardiology Critical Care 2003:56-9.

[6]. Robert S.What Is Basic Life Support?Available from: How.com http://www.ehow.com /facts 5082303 basic-life-support.

[7]. William S. American Heart Association Guidelines for CPR \& Emergency Cardiovascular Care. Circulation 2005;1 V:190-203.

[8]. Parashar A K. Effective planned teaching programme on knowledge \& practice of basic life support among students in Mangalore. Nursing Journal of India 2010;2:14.

[9]. Velhal GD. Assess the knowledge about BLS-CPR among students, Bombay. Nursing Journal of India $2004: 75$.

[10]. Miro O, Jimenez FX, Diaz N, Vincent CB, Bragulat E. Basic CPR programme for high school students (PROCESS) result from the pilot programme. Nursing Journal of India 2002:18-22.

[11]. Battacharya S. A valid and reliable method for evaluator resuscitation. Resuscitation 2000;32:85-93. 